\title{
ДАННЫЕ В МЕДИЦИНСКИХ УЧРЕЖДЕНИЯХ
}

\author{
Акаев С. Д., Ахмадов А.У. \\ Чеченский государственный университет, Грозный
}

В статье рассматриваются медицинские данные пачиентов, и работа, производимая сними, а также способы обеспечения защиты. Целью обработки, хранения и редактирования данных в цифровом виде является удобство. Рассматривается федеральный закон о персональных данных.

Ключевые слова: медичина, медицинские данные, данные в учреждениях, идентификачия, аутентификаџия, авторизаџия.

Мало таких людей, которые могли бы утверждать, что медицина не является важной отраслью для людей. Но найдутся люди, которые могут не согласиться с утверждением, что анализ и обработка данных является очень важной составляющей частью эффективной работы медицинских учреждений и промышленности [1].

С появлением компьютеров работать с данными стало более проще, из-за возможности быстрого редактирования. Бывают такие моменты, когда, по силе производственной необходимости, приходиться изменять, а иногда и вовсе удалять информацию из документа.

При работе с медицинскими данными приходиться работать более внимательно, чем надо было бы если бы речь шла о общественной информации. [2]. Это обусловлено тем, что даже маленькая погрешность в данных может повлиять на здоровье людей. К примеру, если перепутать назначение лекарств пациентов или если пациентов определяют по номерам и что-то там поменять. 
По данным Российского экономического положения и здоровья населения России процент населения страны обратившихся за помощью в частные организации составляет $6.8 \%$. Безусловно данный показатель не является преобладающей, но тем не менее контроль над тем как идет взаимодействие с персональными данными пациентов и сотрудников медицинских учреждений должна проводиться регулярно [3].

Обеспечение целостности данных можно получить путем использования трех процессов, известных в индустрии информационных технологий (ИТ) как: идентификация, аутентификация и авторизация [4].

Первый является первым шагом защиты данных от их изменения мошенниками, это распознавание лица по имени, логину, номеру паспорта и т.д. вторым шагом является процедура проверки подлинности личности, то есть тот, кто пытается войти в систему на самом деле является тем, за кого он себя выдает (аутентификация). И последним является авторизация, это предоставление доступа к контенту (данным). Вышеперечисленные процессы являются самыми базовыми и необходимыми методами защиты данных хранящихся в программе(базе).

Закон Российской Федерации также защищает персональные данные граждан своей страны, которые являются медицинскими пациентами: Законодательство запрещает предоставлять третьим лицам и распространять персональные данные без согласия пациента (ст. 7 Закона № 152-Ф3) [5].

В заключении можно сказать, что работа с данными в медицине является неотъемлемой частью эффективного взаимодействия медицинский учреждений с пациентами. Вместе с этим встает вопрос обеспечения защиты персональных данных пациентов и сотрудников учреждений тоже. Есть ряд мер, которые должны применяться при работе с личными 
данными, а иначе данные могут быть искажены или вовсе потеряны. Поэтому должен быть контроль над работой, которая ведется с персональными данными пациентов и сотрудников в том числе.

\section{Список Литературы}

1. Применение пакета прикладных программ STATISTICA. O.Ю. Реброва. М.: МедиаСфера, 2006 IV изд. 312 с.

2. Защита данных: научное издание / Лазарев В.В., отв. ред., Гаджиев Х.И., отв. ред. - Москва: ЮРИДИЧЕСКАЯ ФИРМА КОНТРАКТ, 2020. - 174 c.

3. XIII Международная научная конференция по проблемам развития экономики и общества. В 4 кн. Кн. 3. Под редакцией: Е. Г. Ясин Кн. 3. М.: Издательский дом НИУ ВШЭ, 2012.

4. Бондаренко С. ИТ уроки. [Электронный ресурс] //. Идентификация, аутентификация, авторизация — в чем разница? URL: http://ituroki.ru/uroki/bezopasnost/identifikaciya-autentifikaciyaavtorizaciya.html (16.10.2020).

5. Федеральный закон от 27 июля 2006 г. N 152-Ф3 «О персональных данных» // «Российская газета» от 29 июля 2006 г.

The article discusses the medical data of patients and the work done with them, as well as ways to ensure protection. The purpose of processing, storing, and editing digital data for convenience. The Federal law on personal data is being considered.

Keywords: medicine, medical data, data in institutions, identification, authentication, authorization. 